\title{
The Role of Digital Economy to Enhancing Sustainable Economic Development
}

\author{
Nur Aini Fitriya Ardiani Aniqoh* \\ Faculty of Islamic Economics and Business, State Islamic University Walisongo, Semarang, Indonesia
}

\section{A R T I C L E I N F O}

Article history: 2020

Received in revised form 02 October 2020

Accepted 18 October 2020

Available online 01

November 2020

Keywords:

Digital Economy,

Sustainability, Sustainable

Economic Development
Received 28 September

\begin{abstract}
A B S T R A C T
This study analyzes The Role of Digital Economy to Enhancing Sustainable Economic Development. The general objective of this research is to assist the government in determining the right policy on the implement of digital economy and its impact on the the sustainable economic development, especially in Indonesia. In Indonesia the digital economy has increasingly developed in the field of ecommerce. The ecommerce industry is not merely talking about buying and selling goods and services via the internet. But there are also other things in it such as inter-service providers, telecommunications providers and others. This is the reason why the ecommerce industry must be adapted to be able to push the economic pace forward. The government is currently declaring Indonesia as the largest digital economy in 2020 and is targeted to be the largest in Southeast Asia. One of the foundations of national development in this declaration is the digital sector. The government targets ecommerce transactions to reach US $\$ 130$ billion and creates 1,000 technopreneur with a business value of US $\$ 10$ billion in 2020. Therefore this research will provide
\end{abstract} policy benefits in strengthening government institutions in order to control the implementation of digital economy in Indonesia so that it give the positive impact on the sustainable economic development to be able to prosper the community and have a positive impact on the environment and increasing the economic value.

Copyright (c) Universitas Pendidikan Ganesha. All rights reserved.

\section{Introduction}

The digital economy was born and developed as the use of information and communication technology is also increasingly globalized in the world. The wave of the digital economy comes with a sloping topography, inclusive, and stretch the quality of opportunity (Tapscott, 1997). This characteristic has the concept of competition which is an industrial spirit that is easily elevated by startups who prioritize collaboration and synergy. Because of this, the digital economy is a 'sharing economy' which elevates many small and medium business to enter the world business.

Digital economy is a thing that signifies the development and economic growth in the future, marked by the rapid development of business or trade transactions that use the internet as a medium in communication, collaboration and cooperation between companies or individuals. The concept of digital economy was first introduced by "(Tapscott, 1997), which is a sociopolitical and economic system that has the characteristics of an intelligence space, including information, various information access instruments, information capacity and information processing. The components of the digital economy that were identified for the first time were the ICT industry, e-commerce activities, digital distribution of goods and services. The concept of digital economy, said (Bolwijn,etal.,2018), according to him, the concept is often used to explain the global impact of information and communication technology, not only on the internet but also in the economic field. Become a view of the interaction between the development of innovation and technological progress that has an impact on macro and micro economics.

In Indonesia the digital economy has increasingly developed in the field of ecommerce. The ecommerce industry is not merely talking about buying and selling goods and services via the internet. But there are also other things in it such as inter-service providers, telecommunications providers and others. This is the reason why the ecommerce industry must be adapted to be able to push the economic pace forward.

\footnotetext{
*Corresponding author.

E-mail address: nurainifaa@walisonongo.ac.id
} 
This research give a lot of advantage for the government to focus on digital economy in order to give the positive impact for sustainability economic development to save the environment and increasing the economic value. Sustainable economic development is economic development that attempts to satisfy the needs of humans but in manner that sustains natural resources and the environment for future generations. Sustainable Economic Development Strategies generate substantial economic and employment growth and sustainable business and community development by demonstrating that innovation, efficiency, and conservation in the use and reuse of all natural and human resources is the best way to increase jobs, incomes, productivity, and competitiveness. In addition, Sustainable Economic Development Strategies are the most cost-effective method of promoting renewable energy and clean technologies, protecting the environment, and preventing harmful impacts from climate change. By implementing Sustainable Economic Development Strategies based on technological innovation and resource efficiency, places can grow their economies, improve their standards of living, and expand businesses, jobs, and incomes.

The government is currently declaring Indonesia as the largest digital economy in 2020 and is targeted to be the largest in Southeast Asia. One of the foundations of national development in this declaration is the digital sector. The government targets ecommerce transactions to reach US \$130 billion and creates 1,000 technopreneur with a business value of US \$10 billion in 2020. (Measuring the Digital Economy Policy Paper, 2019). Therefore, this study focus on the role of digital economy to enhancing sustainable economic development in Indonesia.

Basically, the general objective of this research is to assist the government in determining the right policy on the implement of digital economy and its impact on the sustainable economic development, especially in Indonesia. This research will provide policy benefits in strengthening government institutions in order to control the implementation of digital economy in Indonesia so that it give the positive impact on the sustainable economic development to be able to prosper the community and have a positive impact on the environment

Furthermore, the previous study relate to the digital economy is about special issue on the "The Digital Economy for Economic Development: Free Flow of Data and Supporting Policies". The digital economy provides ample opportunities for G20 economies to accelerate inclusive economic growth. The policies for the flow of data and data-related businesses are still underdeveloped and fragmented across countries. Nevertheless, although ample controversy exists, G20 economies must design and implement a series of policies as soon as possible. This paper will complement the previous study to make more comprehensive related to impact on the sustainable economic development in Indonesia.

\section{Methods}

In conducting research, researchers used qualitative methods for this journal " The Role of Digital Economy to Enhancing Sustainable Economic Development In Indonesia”. In conducting the research, the researcher used primary data through interviews with government agencies ,the Ministry of Finance, in this study it was analyzed using qualitative descriptive analysis, namely by means of data obtained from interviews with informants described as a whole and secondary data from various source whose validity can be justified. The scope of research in this journal focuses on digital economic research that has an impact on sustainable economic development in Indonesia.

\section{Results and Discussions}

The digital economy continues developing, Indonesia has great potential because of the level of penetration Internet user increased. In 2017, number of internet users at Indonesia reached 143.26 million lives or increased by 7.96 percent compared to 2016 for 132.7 inhabitants. Number of users the internet in 2017 accounted for 54.68 percent of the total Indonesia's population is reaching 262 million inhabitants. Indonesian government in the era of President Joko Widodo target Indonesia to be the greatest power of the digital economy in ASEAN in 2020 with e-commerce transaction value projections reached 130 million USD. The concept of a digital economy first introduced by Don Tapscott (The Digital Economy, 1997), which is a sociopolitical and economic system that has characteristics as a space intelligence, including information, various instrument access, capacity, and information processing. Components of a digital economy that are first identified time is the technology industry, information and communication (ICT), e-commerce activities, and distribution digital goods and services. (Tapscott, 1997)

Basically, Digital Economy has significant impact on Indonesian economy. The Statistics Center shows, in 2017 market contribution digital towards Domestic Products Indonesia's gross (GDP) increased 4 percent compared to 2016 by 3.61 percent, and year 2018 is estimated at 10 percent. Based on Report 
Oxford Economics in 2016, every 1 percent increase in penetration mobile is projected to contribute an additional 640 million USD to GDP Indonesia and open 10,700 new jobs in 2020. Behind that, economic development digital if not immediately addressed can have several effects negative, including unemployment. (Economic, 2018)

Indonesia is a great location for digital economic growth. Based on Temasek's report, Indonesia's digital economy this year scored USD 40 billion or IDR 556.6 trillion (USD $1=$ IDR 14,166). Digital economic growth figures are the highest in Southeast Asia this year, beating Thailand (USD 16 billion), Singapore (USD 12 billion), Vietnam (Rp 12 billion), Malaysia (USD 11 billion), and the Philippines (USD 7 billion). So that,the growth of Indonesia's digital economy sector is supported by e-commerce which in four years grew 12.3 times to USD 21 billion. In 2025, growth could reach USD 82 billion. (Temasek, 2020) There are some factors that give influence for developing of digital economy in Indonesia:

\section{Demography}

Digital economy is encouraging people become productive with utilizing technology and with demographic bonus expected the younger generation has more control technological development. Mastery of digital technology is one of the things that can still be said to be minimal in Indonesia. This is what must be anticipated and completed by the government ahead of the demographic bonus. Bonus demographics will be maximal if productive age population has decent health, education and adequate skills. If technological progress is not accompanied by skills community in utilizing that technology, then Indonesia it is feared will only become audience and product market share foreign. Basically, the demographic bonus must be accompanied by the use of digital technology in order to have a positive impact in encouraging the growth of millennial generations to become leaders in e commerce, startups and digital economic development in Indonesia. Industrial relations arrangements involving government, employers and workers must also be able to respond to the effects of changes caused by the digital economy. The preparation of regulations on industrial relations must be adaptive to changes in the digital economy. (Company, 2013)

\section{Infrastructure}

Nowdays, the Indonesian government is still focused on infrastructure development. Not only physical infrastructure but also digital infrastructure. Technological developments must be accompanied by supporting capabilities and access, one of which is internet access. Because to be able to maximize the benefits of digital technology not only requires electricity but also the internet. In fact, several cities in Indonesia do not yet have internet access because the infrastructure is not yet stable.

Basically Indonesia's Internet penetration is 34 percent. The current rate is half that of ASEAN neighbor Malaysia and far behind that of leaders such as the United Kingdom, Japan, and Canada. Indeed, its relatively larger population means that Indonesia is home to the world's third-largest population of individuals without access to the Internet. Geographically, digitization is uneven across Indonesia, with Internet penetration strongly correlated to income per capita; poorer regions have lower penetration. Only the large population centers such as Jakarta and Yogyakarta have a penetration rate above 45 percent. (Guo et al., 2017)

Furthermore, Indonesia's performance has dramatically improved in the past 12 months with the introduction of 4G, there are three clear opportunities to further improve Indonesia's infrastructure in the near term:

1. International linkages. With a large portion of Indonesia's traffic going to international sites such as Facebook and Google, international bandwidth is an important consideration for planning Indonesia's digital future. According to Telegeography, Indonesia's international capacity is limited, with only 0.01 megabytes per second (mbps) per user compared with Singapore with 2.74 mbps per user.5 Connectivity is also concentrated, with most lines going through Singapore-a situation that leads to less than competitive pricing (Exhibit 4).6 40 percent of landing points are located in just three cities (Batam, Dumai, and Jakarta).

2. Domestic cable network. Data traffic in Indonesia is expected to rise sixfold by 2020, placing pressure on the capacity of the domestic network7-that is, the linkages through submarine and overland fiber optic.

3. 4G infrastructure. Indonesia's last-mile 4G coverage was at only 23 percent in 2015.10 Growing e-commerce, mobile entertainment, and gaming content have increased the need for speed for the 73 percent of Indonesia's users that access the Internet through mobile broadband.11 The country must enhance 4G/LTE infrastructure outside Java to enable users to take advantage of the falling handset prices and increase $4 \mathrm{G}$ penetration beyond the 2015 level of 7.6 percent.12 With the recent enabling of critical spectrum assets for $4 \mathrm{G}$, operators have already started moving aggressively in this direction. 
Moreover, Digital infrastructure development provides effect multiplier in other infrastructure sectors. There are at least 12 benefits, namely driving the digital economy, key to industry 4.0, encouraging new investment, growing economy, equalizing education, encouraging competitiveness, supporting the environment, implementing new technologies, new jobs, the startup industry, unifying the nation, and raising the quality life. Macro digital infrastructure will encourage national economic growth, encourage national competitiveness, and encourage new investment.

\section{Education}

Digital platforms increase access to education and becoming important tool in building a community-based knowledge. E-learning can increase opportunities learning, acting as a platform for development skills, and encourage development in the area rural and remote. This can lead to improvement quality of life for individuals and their families, which later will trigger a good cycle, which encourages growth economy, create more jobs, and reduce poverty.

Indonesia has the fourth largest education system in the world, with more than 50 million students and around 4 million teachers, who many of them do not meet the qualifications. However, although government spending on education exceeds the budget for the nation's health, education this is also one of the most performing fields low.

According to the Consumer Survey from GSMA Inteligence, 17.4\% of people aged 18-24 years access information to support their education or children or relatives them with a cellphone every month. M Learning students can save a lot of their training costs compared with traditional classes, especially in the absence of costs travel required to attend the training. In 2015, Ministry of Education and Indonesian Culture initiated the initiative which aims to replace physical textbooks at school (which is expensive and difficult to obtain and distribute) with tablets and ebook.

The first round of funding from the GSMA Ecosystem Accelerator Innovation Fund 4.0 results in the availability of funds for Ruang guru from Indonesia. Ruang guru is a provider technology-based education and launched in the year 2014. Its flagship product, Ruang Kelas, is a management system free premium learning (freemium) that helps students prepare for exams using customized content with a national curriculum, and help teachers do crowdsource to gather educational and content distribute it to students. This increases student learning experiences and improve teacher access to necessary resources.

\section{Financial Technology}

This digital and fintech economy has many benefits for the economic system in Indonesia. Both in terms of consumers, service providers, and the state as a regulator of the flow of the economy. This is what makes fintech considered to provide great opportunities as an alternative to solving national financial problems. Because its growth always gives a good diagram in each of its movements, especially in the national financial credit system.

This can be seen from the increasing lending to the micro and small and medium business sector. Even in January 2019, according to the Financial Services Authority (OJK) data, the accumulated amount of loan disbursement reached IDR 25.59 Trillion from 99 registered financing fintech. The good ecosystem produces more transactions than lending. This has regular implication, for example, an entrepreneur uses fintech services to borrow capital. Then the business is successful and smooth in matters of repaying the loan, automatically the entrepreneur will make another loan to develop his business. This easy access to loans makes fintech a competitor in the banking world as an alternative to solving financial problems. The rapid growth of the domestic fintech platform, gave birth to various types of similar companies that were also present in it.

The platforms currently on top of the current national economy are fintech and e-commerce. The two manifestos which are predicted as economic unicorns, especially digital, are increasingly showing fangs in moving the domestic economy. The great opportunity for the fast turn of the economic wheel in the digital era as it is today, demands that fintech and e-commerce as a digital platform can contribute to the ongoing development of the economy in the economic sector. The real time system that is the reference is also expected to attract investors to attend from January to August 2017 the investment value in fintech was 20 percent. While the investment value obtained by e-commerce rose by 21 percent. This is certainly very interesting to note, especially by the government as a regulator as well as regulatory supervisor. (Rosadi \& Tahira,2018)

Basically, there are four things that must be met by the government and industry so that investment can continue. First, move quickly in responding to technological developments. Second, collaboration between the government and the private sector with decentralization regulations. The third point is to develop data to build a wise and established digital ecosystem. While the fourth, developing and combining the offline and online industries in order to complement each other and provide benefits. 
Meanwhile, for the number of start-ups in Indonesia alone, reaching 1,716 as of February 2018. This figure is far greater than the neighboring country, Singapore 511, while Malaysia only has 146 start-ups. This will certainly be more interesting to develop so that the domestic economy continues to show good progress. (Nurdany \& Kresnowati,2019)

In addition, interwoven cooperation, for fintech lending, e-commerce is useful for providing data or transaction records of prospective buyers or business people on electronic trading platforms who want to borrow funds. In addition, the presence of fintech lending for e-commerce is expected to provide an alternative method of payment that is easier and more effective.

\section{Digital Economy Opportunities and Challenges}

The rapid technological developments that occur affect business behavior and global economic conditions, so that the digital economy is born. Now the internet world has developed so rapidly that the banking, fintech, and even financial industries such as insurance have also moved on the internet platform.

Financial applications are growing along with the increasing number of users who use them. Starting from making a budget, calculating profit and loss, interest on loans, insurance, to digital payments, thrives in the form of applications. The term bank in your hand feels like it has been applied.

There are five technologies that have the most potential to trigger digital economic growth in the Southeast Asian region, those are mobile internet, big data, internet of things, automation of knowledge, and cloud technology. The development of Indonesia's digital economy has been in the global spotlight since 2016 when Gojek received funding so that it has a valuation of US \$ 1 billion. With such a large valuation, this startup will be a unicorn group. (Rosadi \& Tahira, 2018)

The digital economy in Indonesia is realized in a variety of industries. Not only focused on finctech alone, but the digital economy has now also penetrated into the fields of transportation, financial banking, agriculture, to urban planning. The development of the digital economy itself is directly proportional to the use of the internet in Indonesia. One proof of this is the proliferation of various start-up efforts, even now 4 of them have a Unicorn title.

It is known that the financial technology industry to the Indonesian economy reached Rp. 25.97 trillion. This was revealed in a study by the Institute for Development of Economics and Finance together with the Indonesian Fintech Association in 2019. The development of fintech in Indonesia was able to increase Gross Domestic Product or GDP by Rp25.97 trillion, both directly and indirectly. In addition, household consumption was able to increase to Rp8.94 trillion. Both of these shows the existence of fintech has been able to improve the Indonesian economy in a way macro.

On the other hand, if we pay attention to the various complaints from the start-up actors, and also by a number of people, regulatory issues are still a stumbling block to various ecosystem development and investments. Starting from the many and chaotic various regulations of different ministries / institutions in terms of regulating its establishment, to the lack of conducive existing regulations in regulating start-up companies to go public and to float their shares (Initial Public Offering / IPO) to the domestic stock market.

Since internet access and Wi-Fi are scattered in almost all public facilities, cafes, coffee shops, and campuses, they are connected to the internet. In the past, the internet can only be accessed at internet cafes or using modems, now the internet is in the hands of all of us as long as we carry smartphones. (Bolwijn et al.,2018)

Similar to the change in the way consumers pay from cash to non-cash. If in the past to buy goods must be done in cash, now various payment methods can be chosen by consumers, ranging from credit cards, debit cards, and now there is a digital wallet that is increasingly popularly used by today's society. Moreover, several digital wallet brands, such as GO-PAY, OVO, Dana, etc. regularly hold cashback promos that make people interested in trying and buying products in stores that work with this digital wallet.

All we have to do is scan the QR Code and confirm the order with a PIN, we can pay easily. There is no such thing as change with candy or bring change from transactions because all payments are made in non-cash with the help of financial technology. Aside from being practical, this new payment method also makes it increasingly rare for people to carry large amounts of cash to conduct transactions.

Likewise, when buying products at an online store, simply by transferring, we can get the product in front of our house with the shipping service provided. The development of the digital economy is changing the psychological of Indonesian people in general, which is increasingly wanting to be fast, practical, and easy to get the desired product.

The various advancements brought about by the digital economy have had various impacts on the lives of Indonesian people. On the one hand, the digital economy opens up various professions and new 
business opportunities by utilizing digital technology, such as online shops, online motorcycle taxis, celebgrams, YouTubers, digital wallets, and various elements that involve the digital world.

Basically, the digital economy has also become a threat to conventional businesses and professions that were popular in the previous era, such as cellphone kiosks, credit kiosks, cashiers, toll guards, and various other things that began to disappear slowly over time. Officers who used to regularly guard to receive money, have now turned into e-Toll card reader machines that are ready to work 24 hours to receive digital money from consumers.

In addition, the digital economy has also succeeded in avoiding the potential for miss use of transactions by irresponsible parties. The existence of a track record or transaction history is evidence of a financial transaction that can be accounted for. The digital economy also prevents brokering practices that were often carried out on trains or airplanes which used to be very common in Indonesia. Online systems provide security, as well as security for all parties involved in this digital economy.

\section{Sustainable Economic Development In Indonesia}

Sustainable development must completely overhaul the current conventional development paradigm. The interests of development in the short term must be more balanced with the interests of the long term. Social and environmental interests must be placed in a position that is equal to economic interests. Social interests of the community must be more aligned with individual interests. Market failures must be corrected, and social and environmental costs must be internalized in the form of economic costs. Government failures must be overcome through equal triangle partnerships between government, corporations and civil society. Civil society groups and society in general must play an important role in the decision making process in sustainable development. (Vincent, Jeffrey R., Theodore Panayotou, 1997)

This paradigm shift requires a change in values and orientation. It is necessary to continually develop new and totally different values of sustainable development from those in conventional development. Education and human resource development can encourage the creation of these new values. Human resources must not only be equipped with skills to achieve economic goals, but also skills to achieve social and environmental goals. For this reason, it requires the integration of science and technology that can holistically manage the interests of economic, social and environmental development. (A., 2009)

The sustainable development paradigm must utilize incentives in the form of economic benefits, prestigious awards and recognition. Examples are needed, appropriate codes of conduct, various regulations, and various internationally recognized standards, such as ISO 9000 for economic standards, ISO 14000 for environmental standards, and ISO 26000 for social standards. The combination of the three ISOs is needed in order to obtain a comprehensive standard that covers economic, social and environmental values simultaneously.

The sustainable development paradigm should also use disincentive to avoid the direction of unsustainable development by applying fiscal instruments, pricing policies, and charging fees to unsustainable behavior. Need regulations, legal provisions with penalties and fines, which encourage people to move towards sustainable development behavior. It also requires the use of moral persuasion through religious teachings, spiritual beliefs, customs and culture. The term one does not live by bread alone provides the basis for developing a more sustainable lifestyle and does not depend on material alone.

Foreign Direct Investment flow into the digital sector is still high and has not declined amid the global economic slowdown. Thus, the digital economy can be a driver of investment performance this year. Specifically, the flow of capital in the digital economy to Indonesia is still strong. We do not see the downward trend or weakening. Even though the trend of global economic growth, starting from Europe, China and the US, has lowered their economic growth target. Capital Investment Coordinating Board assesses that the digital economy and tourism can be a driving force for investment this year and in the years to come. In fact, the two sectors are predicted to be able to take over the movers so far, namely commodities, minerals and other mining products.

The development of the digital sector which is taking place quickly, needs to be responded by the government. Therefore, this sector also needs encouragement from the central, regional and private governments to support economic growth. A very interesting example for investment in Indonesia is the booming of e-commerce and industries related to information and communication technology. We have ecommerce which has a dramatic effect on the economy. This is a new engine of economic growth so as to drive growth above 5\%. Digitalization by start-up companies is now growing to become a unicorn, a privately-owned startup with a capital value of more than US $\$ 1$ billion. 
This challenging opportunity has brought Indonesia to the door of economic competition. It is inevitable, when every local product in all regions of Indonesia must be able to compete at the global level. So that the products produced by the community have competitiveness, of course this becomes an important part, that the online market is a solution to facilitate and introduce their creative products to consumers both nationally and internationally.

One of the Indonesia's government's programs is through the Palapa Ring (national optical fiber network) and satellite launch which is planned to be launched in 2019, which will later serve the needs of fast internet in all regions in Indonesia. Based on research conducted by Google and Temasek, that Southeast Asia has enormous online market potential for future businesses. The report said the online market in Southeast Asia reached USD 200 billion or 2,647 trillion in 2025.

A number of agendas work on the digital economic potential carried out by the government, especially in terms of regulation, for example the Coordinating Ministry for Economic Affairs issued the Economic Policy Package Volume 14 on e-commerce and gave birth to startups through the 1,000 Digital Startup National Movement promoted by the Ministry of Communication and Information in collaboration with relevant parties.

Furthermore, The digital economy in Indonesia is realized in a variety of industries. Not only focused on financial technology alone, but the digital economy has now also penetrated into the fields of transportation, financial banking, agriculture, to urban planning to enhancing sustainable economics development in Indonesia. One important problem faced in economic development is how to deal with the trade-off between meeting the needs of development on the one hand and efforts to maintain environmental sustainability on the other hand (Fauzi,2004).

Continuous development has led to a shift in roles between sectors that were initially agriculture, forestry, fisheries as dominant, then began to spread to other sectors such as mining and quarrying, industry, transportation, services, banking, trade, etc. Even though the economic condition is still difficult does not mean that decision makers in Indonesia are now justified in ignoring environmental problems, which means sacrificing the interests of future generations.

Therefore, although conditions are still difficult, Indonesia with all its components, both at the level of authority (central and regional) and the community, both as producers and consumers, is expected to remain highly committed to continuing to implement sustainable economic development. Not only from the aspect of the natural environment, but also the social environment. In addition, it is very important to reduce the negative economic shock that can cause a crisis to destroy all joints of the economy, the natural environment, and social, thus reducing the threat of damage to the natural environment even more seriously.

\section{Conclusion}

Digital economy has significant role to increase the sustainable economic development because if we look at the growth of the internet in Indonesia which has experienced quite astonishing penetration, while at the same time seeing the population of Indonesia which has now reached 213 million people, Indonesia can certainly be a good destination for economic movers to market their products. In addition, the reasons that make Indonesia a soft market for economic actors, first, e-commerce market growth in Indonesia is also good; second, the population continues to grow, even of 213 million people, $70 \%$ of them are under forty years old; third, the rapid growth of social media users in Indonesia. fourth, the rapid population growth of people with middle and upper economic classes.

\section{Acknowledgement}

Thank you to my colleagues at UIN Walisongo who have provided support to me to write a journal and to the Ministry of Finance who helped me through accurate data to support my journal writing, as well as to IJSSB editors and reviewers who gave suggestions to improve this journal.

\section{References}

A., F. (2009). Rethinking Pembangunan Ekonomi Sumberdaya Alam dan Lingkungan. Artikel dalam buku Orange Book: Pembangunan Ekonomi Berkelanjutan dalam Menghadapi Krisis Ekonomi Global. IPB Press.

Agency, C. S. (2019). Active Internet User. https://www.bps.go.id/.

Bolwijn, R., Casella, B., \& Zhan, J. (2018). International production and the digital economy. In Progress in 
International Business Research (Vol. 13, pp. 39-64). Emerald Group Publishing Ltd. https://doi.org/10.1108/S1745-886220180000013003

Brynjolfsson, E., Y. Hu, and M. D. Smith (2003). "Consumer Surplus in the Digital Economy: Estimating the Value of Increased Product Variety at Online Booksellers.” Management Science 49 (11): 1580- 96.

Cavallo, A. and R. Rigobon (2016). "The Billion Prices Project: Using Online Prices for Measurement and Research", Journal of Economic Perspectives, Vol. 30, No. 2 (Spring), pp. 151-178. http://www.jstor.org/stable/43783711

Company, M. \&. (2013). Internet matters: Essays in digital transformation. Mckinsey.com

Chang, J.-H., Rynhart, G. \& Huynh, P., 2016. ASEAN in Transformation: How Technology is Changing Jobs and Enterprises, International Labour Office, Geneva. http://www.ilo.org/public/english/dialogue/actemp/downloads/publications/2016/asean_in_tra nsf_2016_r1_techn.pdf

Deaton, A. (2013); The Great Escape: Health, Wealth and the Origins of Inequality, Princeton University Press, Princeton and Oxford.

DETF, G. (2018). Toolkit for measuring the digital economy. G20 Digital Economy Task Force. G20 DETF.

Economic, O. (2018). Country Economic Forecasts > Indonesia - Oxford Economics.

Elmasry, T. et al., 2016. Digital Middle East: Transforming the Region into a Leading Digital Economy, McKinsey \& Company, New York, NY. http://www.mckinsey.com/global-themes/middle-eastandafrica/digital-middle-east-transforming-the-region-into-a-leading-digital-economy

Fauzi, Hasan, Svensson, Goran, A. dan A. R. (2010). Triple Bottom Line as Sustainable Corporate Performance: A Proposition for the Future (pp. 1345-1360). Sustainability 2

Florini A., Sovacool B. (2009) Who Governs Energy? The Challenges Facing Global Energy Governance // Energy Policy. Vol. 37. P. 5239-5248.

Gaspareniene L., Remeikiene R., Navickas V. (2016) The Concept of Digital Shadow Economy: Consumer's Attitude // Procedia Economics and Finance. No. 39. P. 502-509.

Guo, S., Ding, W., \& Lanshina, T. (2017). Global Governance and the Role of the G20 in the Emerging Digital Economy. International Organisations Research Journal, 12(4), 169-184. https://doi.org/10.17323/1996-7845-2017-04-169

G20 (2017b) G20 Leaders' Declaration: Shaping an Interconnected World: University of Toronto. Режим доступа: http://www.g20.utoronto.ca/2017/2017-G20-leaders-declaration.html (дата обращения: 23.07. 2017).

He X. (2013) Shuzi Jingji Fazhan Qushiji Woguo de Zhanlve Xuanze [The Development Trend of Digital Economy and the Strategic Choice of China] // Zhong Wai Qiye. P. 41-42. (In Chinese.)

Jorgenson, D. W. and P. Schreyer (2017), 'Measuring Individual Economic Well-Being and Social Welfare Within the Framework of the System of National Accounts', Review of Income and Wealth Series 63, Supplement 2, December 2017,pp. 460-77

Lanshina T., Barinova V. (2017) The Global Governance of Renewable Energy: International Trends and Russia // International Organizations Research Journal. Vol. 12. No. 1. P. 110-126. DOI: 10.17323/1996-7845-2017-01-110.

McFadden, D. (1978); 'Cost, Revenue and Profit Functions' in Production Economics: A Dual Approach to Theory and Applications, Vol. 1, ed. by M. Fuss and D. McFadden (Amsterdam: North-Holland), pp. 3-109.

Measuring the Digital Economy Policy Paper. (2019). https://www.imf.org/en/Publications/PolicyPapers/Issues/2018/04/03/022818-measuring-the-digital-economy.

Mesenbourg T.L. (2001) Measuring the Digital Economy. U.S. Bureau of the Census. Режим доступа: http://www.census.gov/content/dam/Census/library/working-apers/2001/econ/digitalecon.pdf (дата обращения: 23.07.2017).

Molnar, G, S. J. Savage, and D. C. Sicker (2014), Measuring Broadband Internet Prices, Journal on Teleommunications and High Techology Law, Vol 12, Issue 1 (Spring) 
Nations, U. (2019). Draft intergovernmentally agreed conclusions and recommendations submitted by the President of the Economic and Social Council, Inga Rhonda King (Saint Vincent and the Grenadines), on the basis of informal consultations. Follow-up and Review of the Financing for Development Outcomes and the Means of Implementation of the 2030 Agenda for Sustainable Development.

Narlikar A. (2014) Unintended Consequences: The G20 and Global Governance // Caribbean Journal of International Relations \& Diplomacy. Vol. 2. No. 3. P. 61-71.

Nurdany, A., \& Kresnowati, A. M. (2019). Digital-related economy sectors and regional economy disruption. Jurnal Ekonomi Dan Bisnis, 22(1), 147-162. https://doi.org/10.24914/jeb.v22i1.2187

Rosadi, S. D., \& Tahira, Z. (2018). Consumer Protection In Digital Economy Era : Law In Indonesia. Yustisia Jurnal Hukum, 7(1), 81. https://doi.org/10.20961/yustisia.v0i0.20144

Studies, I. (2018). Exploring the Potential of Digitalization for Inclusive Development in Eastern Indonesia.

Shen Z. (2016) Deguo Chuzhaowei Shuzi Jingji 'Tisu' [Measures proposed by Germany to speed up Digital Economy]. Jingji Cankao Bao. (In Chinese.)

Tapscott, D. (1997). The digital economy: promise and peril in the age of networked intelligence. Mc Grawhill.

Tayibnapis, A. Z., E. Wuryaningsih, L., \& Gora, R. (2018). The Development of Digital Economy in Indonesia. International Journal of Management \& Business Studies , 8 (3), 14-18.

Temasek. (2020). Indonesia Digital Economy. In Temasek Foundation www.temasekfoundation.org.

Unit, E. I. (2020). The development of a country's digital economy. https://country.eiu.com/indonesia.

Vincent, Jeffrey R., Theodore Panayotou, and J. M. H. (1997). Resource Depletion and Sustainability in Small Open Economies. Journal of Environmental Economics and Management, 3(33), 36.

Zwijnenburg, J., S. Bournot and F. Giovannelli (2017), “Expert Group on Disparities in a National Accounts Framework: Results from the 2015 Exercise”, OECD Statistics Working Papers, 2016/10, OECD Publishing, Paris. http://dx.doi.org/10.1787/2daa921e-en

Worldbank. (2018). IndonesIa's Rising DiviDe. In -. Pubdocs.worldbank.org. 